\title{
Insecticidal activities and mechanism of extracts from neem leaves against Oxya chinensis
}

\author{
[Atividade e mecanismos inseticidas de extratos de folhas "neem" contra Oxya chinesis] \\ L. Li, X. Song, Z. Yin ${ }^{*}$, R. Jia, Y. Zou \\ Natural Medicine Research Center, College of Veterinary Medicine, Sichuan Agricultural \\ University, Chengdu 611130, China
}

\begin{abstract}
In this study, neem leaves were successively extracted with petroleum ether, $95 \%$ ethanol and water and the insecticidal activities of these extracts against Oxya chinensis larvae were measured. The results showed that $95 \%$ ethanol extract gave the highest extraction yield and insecticidal activity, and it was further extracted with five different solvents. The petroleum ether extract from the $95 \%$ ethanol extract possessed the highest insecticidal activity with median lethal concentration values ranging from 14.93 to $55.66 \mathrm{mg} / \mathrm{mL}$. The gas chromatography-mass spectrometer analysis showed that the petroleum ether extract mainly composed of alkanes, olefin, esters and amide. The pathological examination revealed that the prominent lesions, including reduced regenerative cells in midgut and swelled and degenerated cylindrical cells, were observed in the 5th instar Oxya chinensis after treatment. The ultrastructural features showed that the cylindrical cells, microvilli and mitochondria were seriously damaged. These results suggested that the petroleum ether extract from neem leaves had potent insecticidal activity and could be a candidate insecticide.
\end{abstract}

Keywords: neem leaves, Oxya chinensis, insecticidal activity

\section{RESUMO}

Nesse estudo, folhas "neem" foram extraídas com sucesso com éter de petróleo, $95 \%$ de etanol e água, e as atividades inseticidas desses extratos foram medidas contra larvas de Oxya chinesis. Os resultados mostram que extrato com $95 \%$ de etanol deram o maior resultado de extração e atividade inseticida e foi então extraído utilizando mais cinco diferentes solventes. O éter de petróleo do extrato de $95 \%$ etanol apresentou maior atividade inseticida com concentração letal média variando de 14.93 a $55.66 \mathrm{mg} / \mathrm{mL}$. A análise por cromatografia de massa mostrou que o extrato de éter de petróleo está composto principalmente de alcanos, alcenos, ésteres e amidas. A avaliação patológica revelou que as lesões proeminentes, inclusive células regenerativas reduzidas no intestino e células cilíndricas edemaciadas e degeneradas foram observadas no quinto estágio de desenvolvimento da Oxya chinesis após tratamento. As características ultraestruturais mostraram que as células cilíndricas, microvilos e mitocôndrias apresentavam lesões graves. Esses resultados sugerem que o extrato de éter de petróleo de folhas de "neem" tem atividade inseticida potente e pode ser um candidato a inseticida.

Palavras-chave: folhas nem, Oxya chinesis, atividade inseticida

\section{INTRODUCTION}

Oxya chinensis (Orthoptera: Acridoidae) mainly distributed in Africa, Oceania and Asia. In China, $O$. chinensis is distributed throughout the

Recebido em 4 de abril de 2016

Aceito em 8 de setembro de 2016

* Autor para correspondência (corresponding author)

E-mail: yinzhongq@163.com whole country except Tibet and Qinghai provinces (Yin et al., 2008). O. chinensis is a hazardous pest threatening the production of rice and other gramineous plants. The traditional control method relies on chemical pesticides. However, most of them have drawbacks such as 
resistance, toxicity and environmental contamination (Ba et al., 2013). At present, many bio-pesticides have been applied to control locusts, such as Metarhizium anisopliae, Nosema locustae, Beauveria bassiana, nematodes, entomopoxvirus and egg parasitic wasps (Tounou et al., 2008; Zha et al., 2011; Bitsadze et al., 2013). But it had been proved that these bio-pesticides were not effective enough to control locusts. For a long time, people have been looking for active insecticidal substances from natural products.

Azadirachta indica A. Juss (syn Melia azadirachta L.) commonly known as neem, possessed biocidal activities such as insecticidal and fungicidal, and neem-based pesticides have been recognized as one of the best bio-pesticides all over the world (Montes-Molina et al., 2008; Javed et al., 2008; Anjorin et al., 2008). Azadirachtin isolated from neem was found to have biocidal activity against nearly 400 species of pests (Srinivasan et al., 2011). Neem-based pesticides with excellent insecticidal activity against locusts are labeled as ideal pesticides (Zhang et al., 2004). Extracts of neem with more than 300 known components affect the physiology and behavior of a wide range of insects, mites and nematodes (Wakil et al., 2014; Ebadollahi et al., 2013; Adebayo and Krettli, 2011; Okafor et al., 2010; Du et al., 2008; Tan and Luo, 2011; Simpson et al., 2011). Many compounds with diverse chemical structures and different modes of action are classified as botanical insecticides. In Orthoptera (such as grasshoppers, crickets, locusts), the antifeedant effect seems especially important. A number of species refuse to feed on neem-treated plants for several days, sometimes several weeks (MontesMolina et al., 2008; Lehman et al., 2007; Sharma et al., 2008).

Currently, some compounds that isolated from neem showed insecticidal activity against $\mathrm{O}$. chinensis, such as saponins and azadirachtin (Amtul and Shakoori, 2014). In this paper, our objectives were to isolating the insecticidal active fraction from extracts of neem leaves by column chromatography and studying their insecticidal activity against the $O$. chinensis nymph in vitro and the mechanism of action by the light microscope and transmission electron microscopic.

\section{MATERIALS AND METHODS}

Neem (Azadirachta indica A. Juss) leaves were collected from Panzhihua city in Sichuan Province of China, which was identified by the Pharmacy Laboratory of Sichuan Agricultural University.

Oxya chinensis nymph were collected from the farm of Sichuan Agricultural University, reared in breeding boxes at the condition of $25 \pm 2^{\circ} \mathrm{C}$, 16:8 light duration and $70 \pm 10 \%$ relative humidity, and fed with fresh corn leaves for $2 \mathrm{~d}$. The $5^{\text {th }}$ instar Oxya chinensis were used in the experiments.

Neem leaves were successively extracted with petroleum ether, 95\% ethanol and water. Each extract was taken to dryness under vacuum at $40^{\circ} \mathrm{C}$ and used for the assay of their insecticidal activity. The extraction rate $(\%)$ was calculated as follows:

Extraction rate $(\%)=$ [weight of extract $(\mathrm{g}) /$ weight of neem leaves $(\mathrm{g})] \times 100 \%$

The insecticidal activity was evaluated by leafsoaking and larva-soaking methods. Three extracts were diluted to $25 \mathrm{mg} / \mathrm{mL}$ with water and a small amount of Tween-80 (1\%). Tested insects were dipped into three extractions for $10 \mathrm{~s}$ respectively, and then fed with the corn leaves which were dipped by the same diluted extraction for $3 \mathrm{~s}$. The insecticidal activity was measured by the mortality after $24 \mathrm{~h}, 48 \mathrm{~h}$, and $72 \mathrm{~h}$. Water and tween-80 was used as negative control, and the whole procedure was repeated thrice. The mortality was calculated by the formulas below:

Percentage of mortality $=$ (number of the dead nymph/number of nymph introduced) $\times 100 \%$ Corrected percentage of mortality $=[1-(\mathrm{n}$ in $\mathrm{T}$ after treatment / $\mathrm{n}$ in $\mathrm{C}$ after treatment) $\mathrm{x} \times 100 \%$

Where " $n$ " is the number of nymph, " $T$ " is the treated group and " $\mathrm{C}$ " is the control group.

The $95 \%$ ethanol extract suspended in water was successively extracted with petroleum ether, chloroform, ethyl acetate and n-butanol, respectively. Then, the petroleum ether extract was fractionated by column chromatography over silica gel G (100 200 mesh) eluted with a- 
hexane/ethyl acetate/acetone (8.5:1:0.5, v/v/v) mixture to give three fractions ( F1-F3) (Du et al., 2009). The five extractions and three fractions (F1-F3) were diluted to 50, 25, 12.5, 6.25 and $3.12 \mathrm{mg} / \mathrm{mL}$ with water and Tween-80, respectively, and their insecticidal activities were measured as described above.

The main components of $\mathrm{F} 1$ were analyzed by GC-MS (Agilent 6890-5973N). The Agilent HP5 column was used and the oven temperature program was as follows: $100^{\circ} \mathrm{C}$ for $3 \mathrm{~min} ; 100^{\circ} \mathrm{C}$ to $120^{\circ} \mathrm{C}, 5^{\circ} \mathrm{C} / \mathrm{min} ; 120^{\circ} \mathrm{C}$ to $280^{\circ} \mathrm{C}, 10^{\circ} \mathrm{C} / \mathrm{min}$; $280^{\circ} \mathrm{C}$ for $10 \mathrm{~min}$. The injector and detector temperatures were $270^{\circ} \mathrm{C}$ and $280^{\circ} \mathrm{C}$, respectively. The Full-scan molecular weight ranged from 45 to 750 .

The midguts tissue of the nymph from posttreatment by the petroleum ether extract after $24 \mathrm{~h}, 48 \mathrm{~h}$ and $72 \mathrm{~h}$ were subjected to histological examination. They were pressed in a fixation medium of $10 \%$ solution of buffered formalin ( $\mathrm{pH}$ 7.4) and enclose in paraffin-intended subsequent histopathological examination. A $5 \mu \mathrm{m}$ section of each organ was stained with hematoxylin and eosin. Each section was examined under an optical microscope.

The transmission electron microscopy assay was conducted using previously established methods (Fichi et al., 2007). The midguts tissue of the nymph was cut off after post-treatment by the petroleum ether extract for $24 \mathrm{~h}, 48 \mathrm{~h}$ and $72 \mathrm{~h}$ and fixed by glutaraldehyde precooling $(2.5 \%, \mathrm{pH}$ 7.2). The tissue was then further fixed with $1.0 \%$ osmic acid followed by dehydration with an acetone gradient prior to embedding. Ultra-thin longitudinal sections were cut and stained with uranyl acetate. The sections were then observed using a transmission electron microscope (JEM1010, Joel, Japan) (Hu et al., 2015).

All results were expressed as a mean \pm standard deviation (S.D.) for the indicated number of experiments. Groups were compared using variance analysis and the Duncan's multiple comparison test (DMRT) by using DPS data processing system. A value of $\mathrm{P}<0$. 05 was considered significant.

\section{RESULTS}

The extraction rates of the crude extracts of neem leaves were shown in Table 1. The extraction rates of water, $95 \%$ ethanol and petroleum ether extract were $46.80 \%, 25.93 \%$ and $2.20 \%$, respectively. The insecticidal activities of the crude extracts of neem leaves against $5^{\text {th }}$ instar Oxya chinensis was shown in Table 2. The insecticidal activities of the three extracts were 0 , $10 \%$ and $10 \%$, respectively in $24 \mathrm{~h}, 0,16.67 \%$ and $20 \%$, respectively in $48 \mathrm{~h}$ and $0,26.67 \%$ and $33.33 \%$, respectively in $72 \mathrm{~h}$. The petroleum ether extract was found to have the highest insecticidal activity, and the water extract had no insecticidal activity. The $95 \%$ ethanol extract had a little lower insecticidal activity, but much higher extraction rate than the petroleum ether extract. Thus, the $95 \%$ ethanol extract was further studied.

The $95 \%$ ethanol extract are further purified with petroleum ether, chloroform, ethyl acetate and nbutanol in sequence extracted method, respectively. Mortalities of the Oxya chinensis nymph treated with the five extracts was shown in Table 3. At a concentration of $25 \mathrm{mg} / \mathrm{mL}$, the mortalities of the petroleum ether extract were $23.33 \%, 73.33 \%, 80 \%$; and the mortalities of the chloroform extract were $23.33 \%, 30 \%, 43.33 \%$, in $24 \mathrm{~h}, 48 \mathrm{~h}$, and $72 \mathrm{~h}$, respectively. The ethyl acetate, n-butanol and water extracts were found to have no significant insecticidal activity in all portions. These results indicated that the petroleum ether extract showed the highest insecticidal activity than other extracts in different time. Therefore, it was necessary to conduct a further study on the petroleum ether extract.

Table 1. The extraction rates of the crude extracts of neem leaves

\begin{tabular}{cccc}
\hline Extraction solvent & Solid-liquid ratio & Dry matter $(\mathrm{g})$ & Extraction rate $(\%)$ \\
\hline Petroleum ether & $1: 10$ & 0.44 & 2.20 \\
$95 \%$ ethanol & $1: 10$ & 3.66 & 25.93 \\
Water & $1: 10$ & 9.36 & 46.80 \\
\hline
\end{tabular}


Table 2. Insecticidal activities of the crude extracts of neem leaves against $5^{\text {rd }}$ instar $O$. chinensis

\begin{tabular}{cccc}
\hline \multirow{2}{*}{ The tested samples } & \multicolumn{3}{c}{ Mortalities (mean \pm S.E. \%) } \\
\cline { 2 - 4 } & $24 \mathrm{~h}$ & $48 \mathrm{~h}$ & $72 \mathrm{~h}$ \\
\hline The petroleum ether extract & $10 \pm 0 \mathrm{~cd}$ & $20 \pm 5.77 \mathrm{bc}$ & $33.33 \pm 3.33 \mathrm{a}$ \\
The 95\% ethanol extract & $10 \pm 5.77 \mathrm{~cd}$ & $16.67 \pm 6.67 \mathrm{bc}$ & $26.67 \pm 3.33 \mathrm{ab}$ \\
The water extract & $0 \pm 0 \mathrm{~d}$ & $0 \pm 0 \mathrm{~d}$ & $0 \pm 0 \mathrm{~d}$ \\
Control & $0 \pm 0 \mathrm{~d}$ & $0 \pm 0 \mathrm{~d}$ & $0 \pm 0 \mathrm{~d}$ \\
\hline
\end{tabular}

The difference between data with the different small letter within a column is significant $(\mathrm{P}<0.05)$.

Table 3. Insecticidal activities of five extracts of neem leaves against $5^{\text {rd }}$ instar $O$. chinensis

\begin{tabular}{lccc}
\multirow{2}{*}{ The tested samples } & \multicolumn{3}{c}{ Mortalities (mean \pm S.E. \%) } \\
\cline { 2 - 4 } & $24 \mathrm{~h}$ & $48 \mathrm{~h}$ & $72 \mathrm{~h}$ \\
\hline The petroleum ether extract & $23.33 \pm 3.33 \mathrm{c}$ & $73.33 \pm 8.82 \mathrm{a}$ & $80 \pm 5.77 \mathrm{a}$ \\
The chloroform extract & $23.33 \pm 3.34 \mathrm{c}$ & $30 \pm 10 \mathrm{c}$ & $43.33 \pm 8.82 \mathrm{~b}$ \\
The ethyl acetate extract & $0 \pm 0 \mathrm{~d}$ & $0 \pm 0 \mathrm{~d}$ & $0 \pm 0 \mathrm{~d}$ \\
The n-butanol extract & $0 \pm 0 \mathrm{~d}$ & $0 \pm 0 \mathrm{~d}$ & $0 \pm 0 \mathrm{~d}$ \\
The water residue & $0 \pm 0 \mathrm{~d}$ & $0 \pm 0 \mathrm{~d}$ & $0 \pm 0 \mathrm{~d}$ \\
Control & $0 \pm 0 \mathrm{~d}$ & $0 \pm 0 \mathrm{~d}$ & $0 \pm 0 \mathrm{~d}$ \\
\hline
\end{tabular}

The difference between data with the different small letter within a column is significant $(\mathrm{P}<0.05)$.

The toxicity results of the petroleum ether extract are shown in Table 4, the median lethal concentration $\left(\mathrm{LC}_{50}\right)$ value of the petroleum ether extract to $5^{\text {th }}$ instar Oxya chinensis are $55.66 \mathrm{mg} / \mathrm{mL}, 20.07 \mathrm{mg} / \mathrm{mL}$ and $14.93 \mathrm{mg} / \mathrm{mL}$ in
$24 \mathrm{~h}, 48 \mathrm{~h}$ and $72 \mathrm{~h}$, respectively. These results indicated that the insecticidal activity of petroleum ether extract showed the relation of time-and concentration-dependent.

Table 4. Insecticidal activity of the petroleum ether extract of neem leaves against $5^{\text {rd }}$ instar $O$. chinensis

\begin{tabular}{cccc}
\hline \multirow{2}{*}{ Concentrations $(\mathrm{mg} / \mathrm{mL})$} & \multicolumn{3}{c}{ Mortalities (mean \pm S.E. \%) } \\
\cline { 2 - 4 } & $24 \mathrm{~h}$ & $48 \mathrm{~h}$ & $72 \mathrm{~h}$ \\
50 & $43.33 \pm 13.33 \mathrm{~b}$ & $83.33 \pm 8.82 \mathrm{a}$ & $96.67 \pm 3.33 \mathrm{a}$ \\
25 & $23.33 \pm 3.33 \mathrm{bc}$ & $73.33 \pm 8.82 \mathrm{a}$ & $80 \pm 5.77 \mathrm{a}$ \\
12.5 & $3.70 \pm 3.70 \mathrm{c}$ & $18.15 \pm 13.46 \mathrm{c}$ & $21.48 \pm 11.48 \mathrm{bc}$ \\
6.25 & $0 \pm 0 \mathrm{c}$ & $6.67 \pm 6.67 \mathrm{c}$ & $16.67 \pm 16.67 \mathrm{c}$ \\
3.12 & $0 \pm 0 \mathrm{c}$ & $3.70 \pm 3.70 \mathrm{c}$ & $7.41 \pm 7.41 \mathrm{c}$ \\
Control & $0 \pm 0 \mathrm{c}$ & $0 \pm 0 \mathrm{c}$ & $0 \pm 0 \mathrm{c}$ \\
\hline
\end{tabular}

The difference between data with the different small letter within a column is significant $(\mathrm{P}<0.05)$.

Three fractions (F1-F3) obtained from the petroleum ether extract by column chromatography were tested for insecticidal activities against $5^{\text {th }}$ instar Oxya chinensis. The results were shown in Table 5 to 7 . F1 showed the highest insecticidal activity. It has also shown that the three fractions (F1-F3) displayed insecticidal activity against $5^{\text {th }}$ instar Oxya chinensis in all test time and concentrations.
The identified compounds and retention times have been given in Table 8. The petroleum ether extract consisted mainly of 6 alkanes (pentacosane, hexacosane, heptacosane, nonacosane, triacontane and hentriacontane), 1 olefin (squalene), 2 esters (hexadecanoic acid, ethyl ester and 9, 12, 15-octadecatrienoic acid, ethyl ester, (Z, Z, Z)-) and 1 amide (erucyl amide). 


\section{Insecticidal activities...}

Table 5. Insecticidal activity of F1 of the petroleum ether extract of neem leaves against $5^{\text {rd }}$ instar Oxya chinensis

\begin{tabular}{cccc}
\hline \multirow{2}{*}{ Concentrations $(\mathrm{mg} / \mathrm{mL})$} & \multicolumn{3}{c}{ Mortalities $($ mean \pm S.E. \%) } \\
\cline { 2 - 4 } & $24 \mathrm{~h}$ & $48 \mathrm{~h}$ & $72 \mathrm{~h}$ \\
\hline 50 & $86.67 \pm 8.82 \mathrm{abc}$ & $100 \pm 0 \mathrm{a}$ & - \\
25 & $60 \pm 5.77 \mathrm{bcd}$ & $90 \pm 10 \mathrm{ab}$ & $96.67 \pm 3.33 \mathrm{a}$ \\
12.5 & $43.33 \pm 8.82 \mathrm{de}$ & $76.67 \pm 14.53 \mathrm{abc}$ & $93.33 \pm 3.33 \mathrm{a}$ \\
6.25 & $26.67 \pm 3.33 \mathrm{ef}$ & $60 \pm 5.77 \mathrm{bcd}$ & $90 \pm 10 \mathrm{ab}$ \\
3.12 & $16.67 \pm 3.33 \mathrm{ef}$ & $56.67 \pm 24.04 \mathrm{~cd}$ & $73.33 \pm 17.64 \mathrm{abc}$ \\
Control & $0 \pm 0 \mathrm{f}$ & $0 \pm 0 \mathrm{f}$ & $0 \pm 0 \mathrm{f}$ \\
\hline
\end{tabular}

The difference between data with the different small letter within a column is significant $(\mathrm{P}<0.05)$.

Table 6. Insecticidal activity of F2 of the petroleum ether extract of neem leaves against $5^{\text {rd }}$ instar Oxya chinensis

\begin{tabular}{cccc}
\hline \multirow{2}{*}{ Concentrations $(\mathrm{mg} / \mathrm{mL})$} & \multicolumn{3}{c}{ Mortalities $($ mean \pm S.E. \%) } \\
\cline { 2 - 4 } & $24 \mathrm{~h}$ & $48 \mathrm{~h}$ & $72 \mathrm{~h}$ \\
\hline 50 & $70 \pm 15.28 \mathrm{bc}$ & $93.33 \pm 3.33 \mathrm{a}$ & $100 \pm 0 \mathrm{a}$ \\
25 & $60 \pm 5.77 \mathrm{c}$ & $86.67 \pm 6.67 \mathrm{ab}$ & $96.67 \pm 3.33 \mathrm{a}$ \\
12.5 & $20 \pm 5.77 \mathrm{efg}$ & $53.33 \pm 13.33 \mathrm{~cd}$ & $93.33 \pm 6.67 \mathrm{a}$ \\
6.25 & $13.33 \pm 6.67 \mathrm{fg}$ & $36.67 \pm 8.82 \mathrm{de}$ & $63.33 \pm 6.67 \mathrm{c}$ \\
3.12 & $3.33 \pm 3.33 \mathrm{fg}$ & $6.67 \pm 3.33 \mathrm{fg}$ & $23.33 \pm 8.82 \mathrm{ef}$ \\
Control & $0 \pm 0 \mathrm{f}$ & $0 \pm 0 \mathrm{f}$ & $0 \pm 0 \mathrm{f}$ \\
\hline
\end{tabular}

The difference between data with the different small letter within a column is significant $(\mathrm{P}<0.05)$.

Table 7. Insecticidal activity of F3 of the petroleum ether extract of neem leaves against $5^{\text {rd }}$ instar Oxya chinensis

\begin{tabular}{cccc}
\hline \multirow{2}{*}{ Concentrations $(\mathrm{mg} / \mathrm{mL})$} & \multicolumn{3}{c}{ Mortalities (mean \pm S.E. \%) } \\
\cline { 2 - 4 } & $24 \mathrm{~h}$ & $48 \mathrm{~h}$ & $72 \mathrm{~h}$ \\
\hline 50 & $86.67 \pm 3.33 \mathrm{ab}$ & $100 \pm 0 \mathrm{a}$ & - \\
25 & $43.33 \pm 12.02 \mathrm{~cd}$ & $80 \pm 11.55 \mathrm{ab}$ & $90 \pm 10 \mathrm{a}$ \\
12.5 & $16.67 \pm 16.67 \mathrm{efg}$ & $63.33 \pm 3.33 \mathrm{bc}$ & $80 \pm 5.77 \mathrm{ab}$ \\
6.25 & $13.33 \pm 3.33 \mathrm{efg}$ & $36.67 \pm 14.53 \mathrm{de}$ & $46.67 \pm 8.82 \mathrm{~cd}$ \\
3.12 & $3.33 \pm 3.33 \mathrm{fg}$ & $3.33 \pm 3.33 \mathrm{fg}$ & $26.67 \pm 3.33 \mathrm{def}$ \\
Control & $0 \pm 0 \mathrm{~g}$ & $0 \pm 0 \mathrm{~g}$ & $0 \pm 0 \mathrm{~g}$ \\
\hline
\end{tabular}

The difference between data with the different small letter within a column is significant $(\mathrm{P}<0.05)$

Table 8. Chemical composition of F1 by GC-MS

\begin{tabular}{ccc}
\hline Number & Retention time $(\mathrm{min})$ & Compound name \\
\hline 1 & 18.310 & Hexadecanoic acid,ethyl ester \\
3 & 19.996 & Pentacosane \\
4 & 22.735 & Hexacosane \\
5 & 23.539 & Heptacosane \\
6 & 24.438 & Erucyl amide \\
7 & 25.380 & Squalene \\
8 & 25.906 & Nonacosane \\
9 & 26.772 & Triacontane \\
10 & 28.165 & Hentriacontane \\
\hline
\end{tabular}

Under light microscope, the tissue showed normal structure in the control group (Figure 1A). In the experiment group, after $24 \mathrm{~h}$ treatment, muscle layer of midgut tissue was complete; layer of intestinal wall cells thickened and part of intestinal wall cells fell off; many nuclei of regenerative cells became pyknotic; the regenerative cells were filled with red mesh-like 
material; cylindrical cells swelled and part of them fell off (Figure 1B). After 48h of treatment, muscle layer of midgut tissue was complete; large area of the layer of intestinal wall cells fell off; microvilli disappeared absolutely; regenerative cells of midget were filled with red mesh-like material and nuclei became smaller; cylindrical cells swelled and lots of them occurred fatty degeneration (Figure 1C). After $72 \mathrm{~h}$ treatment, layer of intestinal wall cells almost fell off; leaving only the circular muscle layer which became thinner and stained lighter; circular muscle layer of midget occurred vacuolar degeneration (Figure 1D).
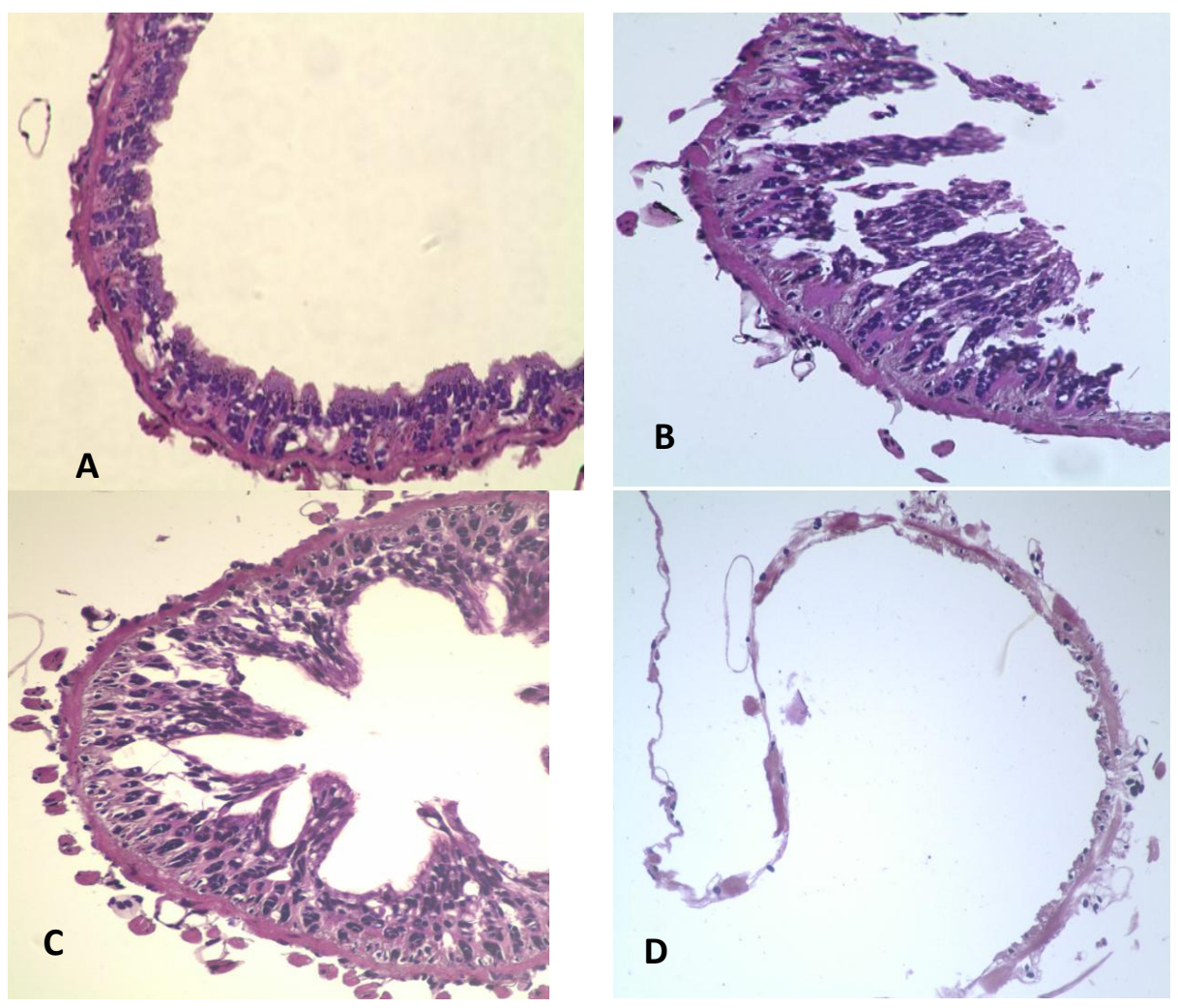

Figure 1 Histopathological changes in the midgut of the Oxya chinensis larvae treated with the petroleum ether extract for different times. A: Control group (H.E. $\times 400$ ), the tissue showed normal structure. B: After 24h treatment (H.E. $\times 400)$, layer of intestinal wall cells thickened and part of intestinal wall cells fell off; many nuclei of regenerative cells became pyknotic; the regenerative cells were filled with red mesh-like material; cylindrical cells swelled and part of them fell off. C :After 48h treatment ( H.E. $\times 400$ ), large area of the layer of intestinal wall cells fell off; microvilli disappeared absolutely; regenerative cells of midget were filled with red mesh-like material and nuclei became smaller; cylindrical cells swelled and lots of them occurred fatty degeneration. D:After 72h treatment (H.E. $\times 200)$, layer of intestinal wall cells almost fell off; leaving only the circular muscle layer which became thinner and stained lighter; circular muscle layer of midget occurred vacuolar degeneration.

Under electron microscopic transmission, in the control group, rough endoplasmic reticulums were orderly with a lot of ribosomes (Figure 2A). After $24 \mathrm{~h}$ of treatment, rough endo-plasmic reticulum decreased in the cytoplasm and the ribosomes began to fall (Figure 2B). After $48 \mathrm{~h}$ of treatment, rough endoplasmic reticulums were disorganized and ribosomes fell off (Figure 2C). After72 h treatment, rough endoplasmic reticulums expanded extremely, fractured and vacuolated (Figure 2D).

In the control group, the microvilli of midgut of the Oxya chinensis nymph were orderly (Figure $3 \mathrm{~A})$. After $24 \mathrm{~h}$ of treatment, microvilli arranged neatly; the pathologic changes were not obvious (Figure 3B). After $48 \mathrm{~h}$ of treatment, microvilli fractured and fell off (Figure 3C). After $72 \mathrm{~h}$ of treatment, microvilli disappeared and a lot of vacuoles appeared (Figure 3D). 

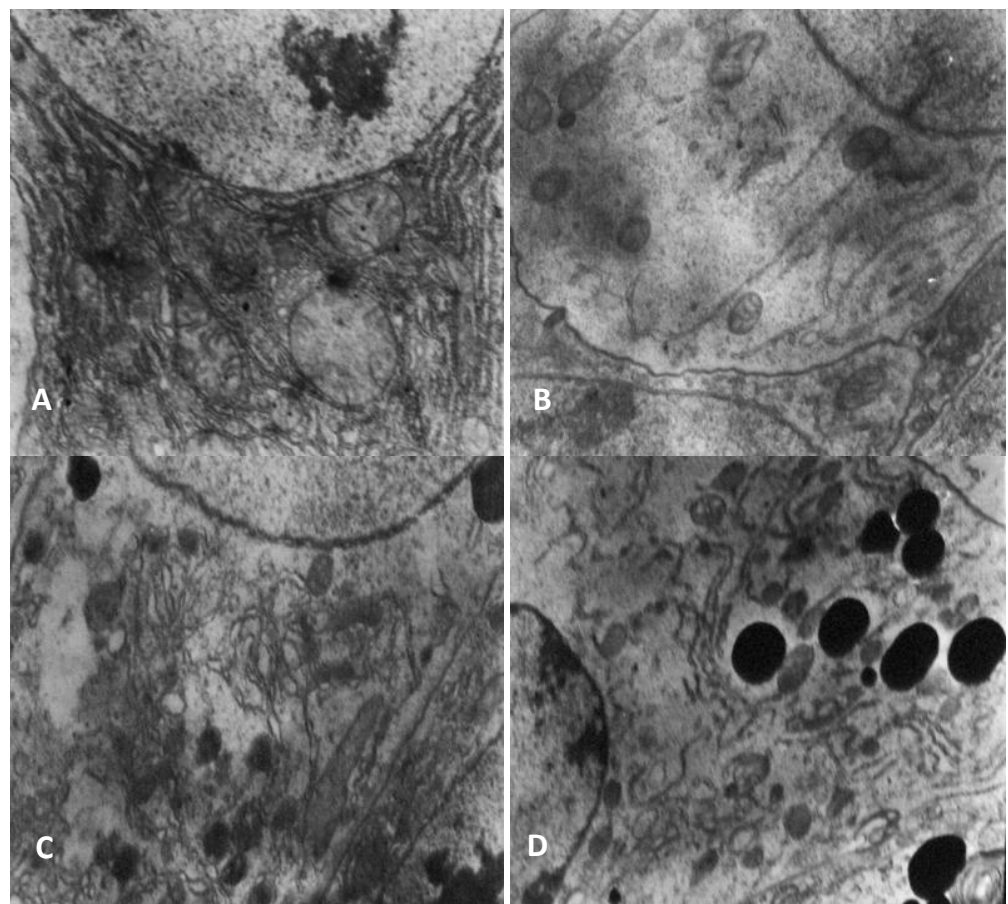

Figure 2 Effects of the petroleum ether extract on the midgut of Oxya chinensis larvae. Control group (A): rough endoplasmic reticulums were orderly with a lot of ribosomes $(\times 15000)$. Experiment group: after $24 \mathrm{~h}$ treatment $(\mathrm{B})$, rough endo-plasmic reticulum decreased in the cytoplasm and the ribosomes began to fall $(\times 12000)$; after $48 \mathrm{~h}$ treatment $(\mathrm{C})$, rough endoplasmic reticulums were disorganized, expanded, and ribosomes fell off $(\times 17000)$; after $72 \mathrm{~h}$ treatment(D), rough endoplasmic reticulums expanded extremely, fractured and vacuolated $(\times 10000)$.

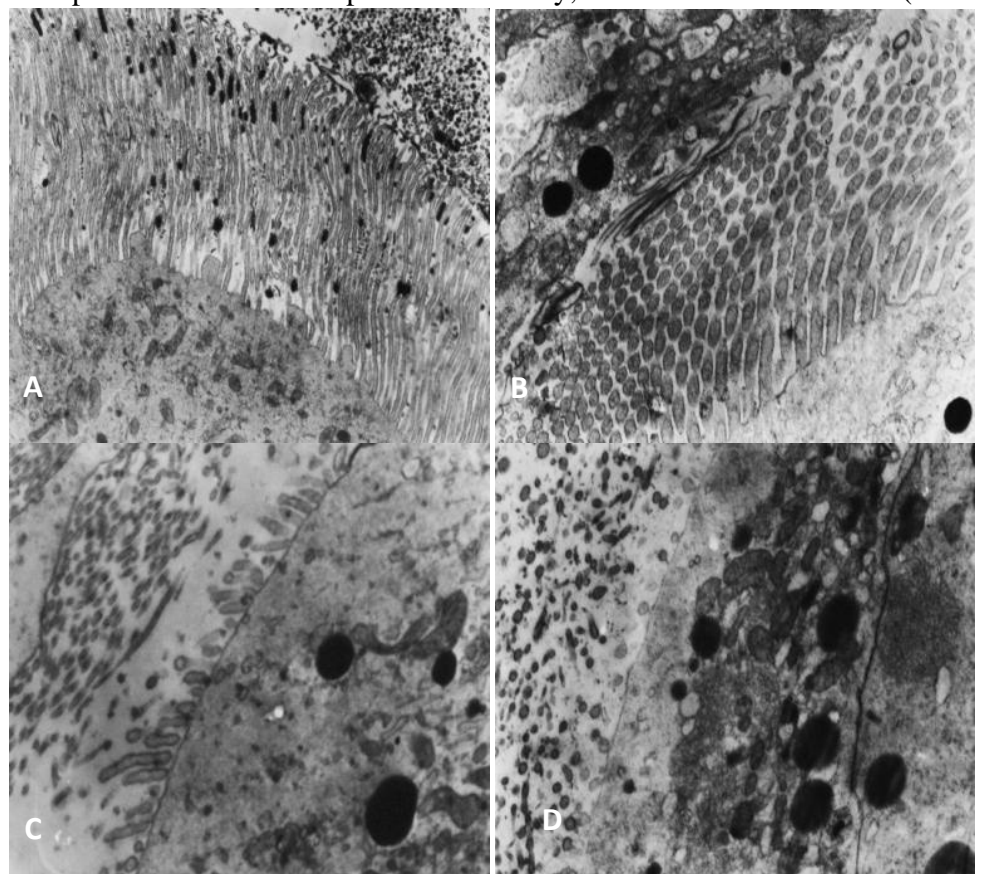

Figure 3. Effects of the petroleum ether extract on the midgut of Oxya chinensis larvae. Control group (A), the microvilli of midgut of the Oxya chinensis larvae was orderly ( $\times 6000)$. Experiment group: after 24h treatment (B), microvilli arranged neatly, the pathologic changes were not obvious $(\times 12000)$; after $48 \mathrm{~h}$ of treatment $(\mathrm{C})$, microvilli fractured and fell off $(\times 15000)$; after $72 \mathrm{~h}$ of treatment $(\mathrm{D})$, microvilli disappeared and a lot of vacuoles appeared $(\times 10000)$. 
In the control group, the mitochondria of the dermis cells were distributed evenly; crest clarity was regularly arranged in the plate layer; the surrounding membrane was clearly observed (Figure 4A). After $24 \mathrm{~h}$ of treatment, mitochondria swelled in different degrees; cristae shortened and decreased (Figure 4B). After $48 \mathrm{~h}$ of treatment, mitochondria swelled obviously; a matrix of mitochondria occurred at electronic clear area; cristae almost disappeared (Figure 4C). After $72 \mathrm{~h}$ of treatment, mitochondria swelled extremely; many vacuoles occurred and broke; myelin figures were observed (Figure 4D).

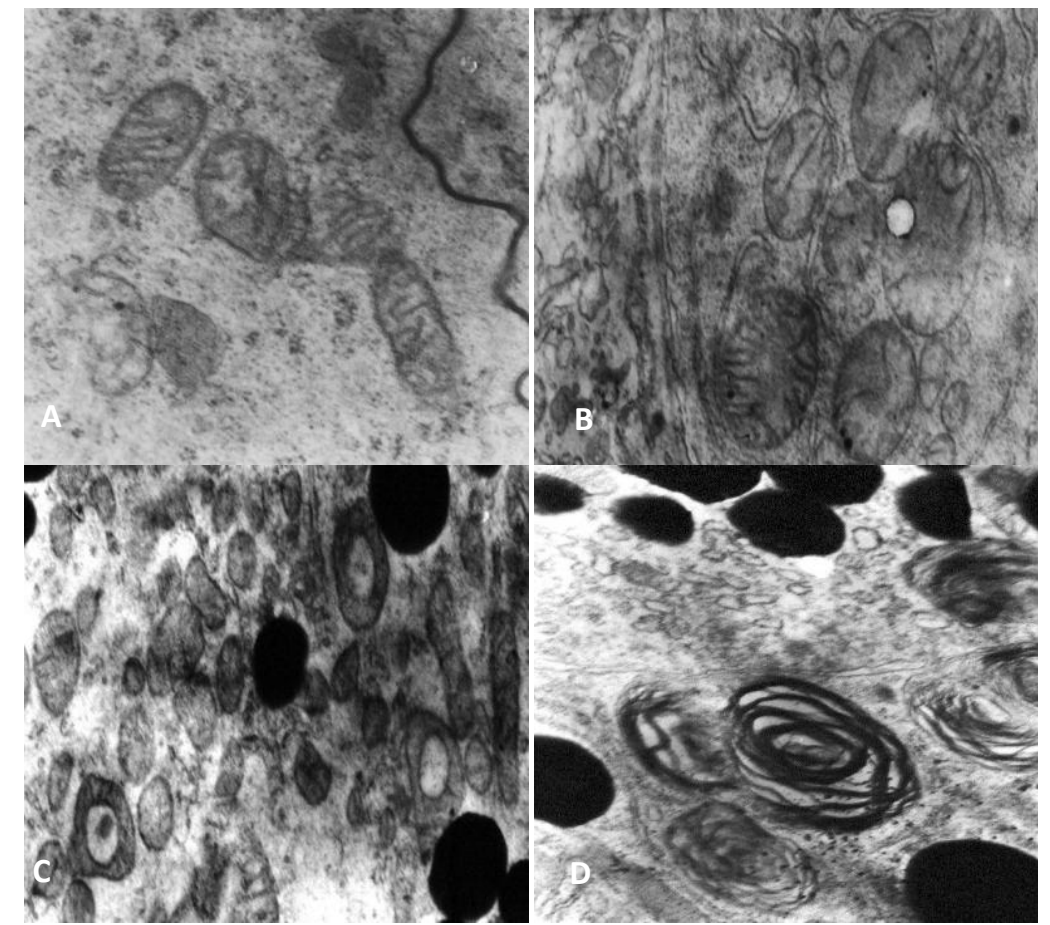

Figure 4. Effects of the petroleum ether extract on the midgut of Oxya chinensis larvae. Control groups (A), the mitochondria of the dermis cells were distributed evenly, crest clarity was regularly arranged in the plate layer, and the surrounding membrane was clearly observed $(\times 30000)$. Experiment group: after $24 \mathrm{~h}$ treatment $(\mathrm{B})$, mitochondria swelled in different degrees; cristae shortened and decreased $(\times 17000)$; after $48 \mathrm{~h}$ treatment $(\mathrm{C})$, mitochondria swelled obviously; a matrix of mitochondria occurred at electronic clear area; cristae almost disappeared $(\times 17000)$; after $72 \mathrm{~h}$ treatment (D), mitochondria swelled extremely; many vacuoles occurred and broke; myelin figures were observed $(\times 20000)$

\section{DISCUSSION}

Neem belonging to the Meliaceae family has been investigated intensively for its potential as a bio-insecticide (Verma et al., 2007; Farooq et al., 2011). The insecticidal activity of neem generally attributes to azadirachtin which is a well-known potent insecticide (Zheng et al., 2011; Kumar et al., 2010). 0.3\% azadirachtin EC $\left(150 \mathrm{~mL} / \mathrm{hm}^{2}\right.$ and $\left.210 \mathrm{hm}^{2}\right)$ was sprayed in the grassland to investigate the control effect on grasshoppers. The results showed that the effects of controlling Calliptamus abbreviate ikovnnikov and Oedaleus decorus asiaticas after 3d were $90.6 \%$ and $92.5 \%$ (Yang et al., 2006). In this study, the results showed that the petroleum ether extract from neem leaves had obvious stomach toxicity against $O$. chinensis nymph from the toxic symptoms and displayed insecticidal activity against $5^{\text {th }}$ instar $O$. chinensis in all test time and concentrations in a time-and concentration-dependent manner. The present study may encourage further researches on using simple and inexpensive application methods for controlling grasshoppers.

The main components of the petroleum ether extract of neem leaves were 6 alkanes, 1 olefin, 2 esters and 1 amide. However, the phytochemical analysis did not reveal the presence of 
Azadirachtin, which has been considered as one of the main active compounds of neem. These results suggested that Azadirachtin was excluded from the petroleum ether extract during our separation process and other compounds from the extract of neem leaves also possessed potent insecticidal activity and could be used as insecticide. In the previous study, we found that octadecanoic acid-tetrahydrofuran-3, 4-diyl ester (ODA-THF) exhibited acaricidal activity against Sarcoptes scabiei var. cuniculi nymph (Du et al., 2009), which will be subject of more studies in further experiments.

The petroleum ether extracts damaged the pivotal organs of the digestive system which was also one of the causes of death. The important reason was the peritrophic membranes disappearance and the midgut cells destruction. The peritrophic membranes are the first obstacle through the foods pass through the digestive tract wall and are an important target for many pesticides (Hegedus et al., 2009). The observed histopathological effects of the petroleum ether extract on the midgut tissue of $O$. chinensis nymph were similar to the results on Mythimna separate and Plutella xylostella (Lü et al., 2010). It stated that the midgut of $O$. chinensis was affected after treatment with the petroleum ether extract and the midgut membrane system was damaged seriously. All the above observations showed that damaging the normal structure of midgut and endomembrane may be one of the primary mechanisms.

Transmission electron microscopy results showed that the autolysis of midgut cells was the main cause of the changes. After $48 \mathrm{~h}$ of treatment, the results showed that midgut cells began to change. The microvilli showed fractures, fell off, and disappeared; partial vacuolation formed. The lysosome increased and organelle started autolysis. Based on the above results, it could be concluded that one of the main reasons was that the midgut cells fell off. But the protease activity of midgut, such as acid phosphatase, needs to be further studied to confirm the results.

\section{ACKNOWLEDGEMENT}

This study was supported by the International cooperation projects of Sichuan Province (2014HH0058, 2013HH0042), the Sichuan
Youth Science and Technology Innovation Research Team for waterfowl disease prevention and control (2013TD0015) and the National Natural Science Foundati on of China (Grant No.31372477).

\section{REFERENCES}

ADEBAYO, J.O; KRETTLI, A.U. Potential antimalarials from Nigerian plants: a review. $J$. Ethnopharmacol., v.2, p.289-302, 2011.

AMTUL, J.S.; SHAKOORI, A.R. Potential of Azadirachtin and neem (Azadirachta indica) based saponins as biopesticides for in vitro insect pests cellulase (Beta-1, 4-Endoglucanase) enzyme inhibition and in vivo repellency on Tribolium castaneum. Br. Biotechnol. J., v.4, p.904-917, 2014.

ANJORIN, S.T.; MAKUN, H.A.; ADESINA, T.; KUDU, I. Effects of Fusarium verticilloides, its metabolites and neem leaf extract on germination and vigour indices of maize (Zea mays L.). Afr. $J$. Biotechnol., v.14, p.2402-2406, 2008.

BA, M.N.; BAOUA, I.B.; N'DIAYE, M. et al. Biological control of the millet head miner Heliocheilus albipunctella in the Sahelian region by augmentative releases of the parasitoid wasp Habrobracon hebetor: effectiveness and farmers' perceptions. Phytoparasitica, v.5, p.569-576, 2013.

BITSADZE, N., JARONSKI S.; KHASDAN, V. et al. Joint action of Beauveria bassiana and the insect growth regulators diflubenzuron and novaluron, on the migratory locust, Locusta migratoria. J. Pest. Sci., v.2, p.293-300, 2013.

DU, Y.H.; JIA, R.Y.; YIN, Z.Q. et al. Acaricidal activity of extracts of neem (Azadirachta indica) oil against the nymph of the rabbit mite Sarcoptes scabiei var. cuniculi in vitro. Vet. Parasitol., v.1, p.144-148, 2008.

DU, Y.H.; LI, J.L.; JIA, R.Y. et al. Acaricidal activity of four fractions and octadecanoic acidtetrahydrofuran-3, 4-diyl ester isolated from chloroform extracts of neem ( Azadirachta indica) oil against Sarcoptes scabiei var. cuniculi nymph in vitro. Vet. Parasitol., v.1, p.175-178, 2009.

EBADOLLAHI, A.; KHOSRAVI, R.; JALALISENDI, J. et al. Toxicity and physiological effects of essential oil from Agastache foeniculum (Pursh) Kuntze against Tribolium castaneum Herbst (Coleoptera: Tenebrionidae) larvae. Annu. Rev. Res. Biol., v.3, p.649-658, 2013.

FAROOQ, M.; JABRAN, K.; CHEEMA, Z.A. et al. The role of allelopathy in agricultural pest management. Pest. Manag. Sci., v.5, p.493-506, 2011. 
FICHI, G.; FLAMINI, G.; GIOVANELLI, F. et al. Efficacy of an essential oil of Eugenia caryophyllata against Psoroptes cuniculi. Exp. Parasitol., v.2, p.168$172,2007$.

HEGEDUS, D.; ERLANDSON, M.; GILLOTT, C.; TOPREK, U. New insights into peritrophic matrix synthesis, architecture, and function. Аnnu. Rev. Etomol., v.54, p.285-302, 2009.

HU, Z.; CHEN, Z.; YIN, Z.J. et al. In vitro acaricidal activity of 1,8-cineole against Sarcoptes scabiei var. cuniculi and regulating effects on enzyme activity. Parasitol. Res., v.114, p.2959-2967, 2015.

JAVED, N.; GOWEN, S.R.; EL-HASSAN, S.A. et al. Efficacy of neem (Azadirachta indica) formulations on biology of root-knot nematodes (Meloidogyne javanica) on tomato. Crop Prot., v.1, p.36-43, 2008.

KUMAR, G.H.; PRIYADARSINI, R.V.; VINOTHINI, G. et al. The neem limonoids azadirachtin and nimbolide inhibit cell proliferation and induce apoptosis in an animal model of oral oncogenesis. Invest. New Drug., v.4, p.392-401, 2010.

LEHMAN, A.D.; DUNKEL, F.V.; KLEIN, R.A. et al. Insect management products from Malian traditional medicine - establishing systematic criteria for their identification. J. Ethnopharmacol., v.2, p.235-249, 2007

LÜ, M.; WU, W.; LIU, H. Effects of fraxinellone on the midgut ultrastructural changes of Mythimna separata Walker. Pestic. Biochem. Physiol., v.2, p.263-268, 2010.

MONTES-MOLINA, J.A.; LUNA-GUIDO, M.L.; ESPINOZA-PAZ, N. et al. Are extracts of neem (Azadirachta indica A. Juss.(L.)) and Gliricidia sepium (Jacquin) an alternative to control pests on maize (Zea mays L.)? Crop Prot., v.3, p.763-774, 2008.

OKAFOR, P.C.; EBENSO, E.E.; EKPE, U.J Azadirachta indica extracts as corrosion inhibitor for mild steel in acid medium. Int. J. Electrochem. Sci., v.5, p.978-993, 2010.

SHARMA, P.R.; SHARMA, O.P.; SAXENA, B.P. Effect of sweet flag rhizome oil (Acorus calamus) on hemogram and ultrastructure of hemocytes of the tobacco armyworm, Spodoptera litura (Lepidoptera: Noctuidae). Micron, v.5, p.544-551, 2008.
SIMPSON, M.; GURR, G.M.; SIMMONS, A.T. et al. Insect attraction to synthetic herbivore-induced plant volatile-treated field crops. Agricult. Forest Entomol., v.1, p.45-57, 2011.

TAN, Q.G.; LUO, X.D. Meliaceous limonoids: chemistry and biological activities. Chem. Rev., v.11, p.7437-7522, 2011

TOUNOU, A.K.; KOOYMAN, C.; DOUROKPINDOU, O.K.; POEHLING, H.M. Interaction between Paranosema locustae and Metarhizium anisopliae var. acridum, two pathogens of the desert locust, Schistocerca gregaria under laboratory conditions. J. Invertebr. Pathol., v.3, p.203-210, 2008.

VERMA, V.C.; GOND, S.K.; KUMAR, A. et al. The endophytic mycoflora of bark, leaf, and stem tissues of Azadirachta indica A. Juss (neem) from Varanasi (India). Microbial. Ecol., v.1, p.119-125, 2007.

WAKIL, W.; GHAZANFAR, M.U.; KWON, Y.J. et al. Testing Paecilomyces lilacinus, diatomaceous earth and Azadirachta indica alone and in combination against cotton aphid (Aphis gossypii Glover)(Insecta: Homoptera: Aphididae). Afr. J. Biotechnol., v.4, p.821-828, 2014.

YANG, H.Z.; ZHANG, Y.H.; KANG, A.G.; LI, Q. Experiment of $0.3 \%$ Azadirachtin emulsion concentrates on controlling grasshoppers. Pestic. Sci. Admin., v.6, p.28-33, 2006.

YIN, K.; MA, E.B.; XUE, C.R. et al. Insecticidal activities of 5-Aminolevulinic acid on Oxya chinensis and effect on three kinds of enzymes. Sci. Agric. Sin., v.7, p.2003-2007, 2008.

ZHA, W.; PENG, X.; CHEN, R. et al. Knockdown of midgut genes by dsRNA-transgenic plant-mediated RNA interference in the hemipteran insect Nilaparvata lugens. PloS One, v.5, p.e20504, 2011.

ZHANG, Z.X.; XU, H.H.; JIANG, D.X.; CHENG, D.M. Prospect of neem-based insecticide controlling locust. Pestic. Sci. Admin., v.7, p.8-13, 2004.

ZHENG, X.; REN, X.; SU, J. Insecticide susceptibility of Cnaphalocrocis medinalis (Lepidoptera: Pyralidae) in China. J. Econ. Entomol., v.2, p.653-658, 2011. 